\title{
The Analogy of Game and Imagination in Art: Paul Ricoeur and Gilles Deleuze's Philosophical Analyses
}

\author{
Haryatmoko, ${ }^{1, *}$ \\ ${ }^{1}$ Universitas Sanata Dharma \\ *Corresponding author.Email: jhmoko59@gmail.com
}

\begin{abstract}
Philosophical discourse on arts by artists can be deemed unnecessary because arts by themselves have been eloquent. However, the present writer is convinced that the cognitive dimension of art is inseparable from discourse. In that way art can trigger intellectual arguments to increase the effectiveness of its expressions through the comparison between art and reasoning. Art has its own rationality, which among others includes the elaboration of the criteria, methods and instruments of its development. In this context, the epistemology of art is very relevant to bridge the gap between art and its rationality. The epistemology of art cannot be ignored in arts education because its object deals with the foundation of art, the conditions of its plausibility, its definitions, the concept of artworks, the relationship between art and its social condition, and particularly the issues of its creativity. In order to examine the genealogy of creativity, the present writer offers two concepts for analyzing the conditions of plausible creativity in art: Paul Ricoeur's games and Gilles Deleuze's deterritorialization with the purpose to explain the relation between imagination and creativity in art.
\end{abstract}

Keywords: genealogy of creativity, Paul Ricoeur's game, deconstruction

\section{THE ANALOGY OF THE GAME: OPENING NEW POSSIBILITIES}

The analogy of games is taken because games are moment full of creativity because, according to Ricoeur, in games freedom is blooming. In freedom, imagination precedes wills which allows the growth of creativity. The analogy of games is part of one of Ricoeur's hermeneutic categories, which is called appropriation or selfunderstanding. Self-understanding signifies the encounter between the world presented by texs and the reader's/interpreter's concrete world. Gadamer uses the expression fusion of horizons to refer to the encounter of the two, or even more, worlds.

It is a fusion of horizons because for the readers/audience it is not possible to take over the whole worlds of texts/art works and leave the actual world where now they live so that they cannot allow their world to remain the same and at the same time cannot reject the worlds offered by the art works/texts they are discerning. The audience's world is undergoing transformation. This category is directly related with the audience's/interpreter's being. Therefore, Ricoeur also uses the term transfiguration (or mimesis III) of human acts. This happens due to the influence of texts/art works they face, which leads to selftransformation or which helps understand themselves better. In the process of self-understanding, self-distancing is an absoulte prerequisite to prevent the distortion of meaning and to relativize arbitrariness in interpretation and appreciation. This self-distancing as a critical or negative aspect is also creative in nature because it will enrich and purify self-understanding. This self-distancing can be in the form of ideological criticism, deconstruction, and games analogy. Ideological criticism and deconstruction are very much coloured by the thoughts of prejudice philosophers: Nietzsche, Marx and Freud. meaning behind what is revealed?" Thus, in Freud's perspective, the issue of interpretation is not only to rectify awareness of a certain mistake, but it is more to overcome false awareness in such away so that not only examination but also, more importantly, healing are required. (J.E.Smith 1995:158). Through deconstruction, the readers/audiences are invited to deconstruct their illusions and motivations, both conscious and subconscious, and self- or group-interests in facing texts/art works.

While ideological criticism and deconstruction are the negative dimensions of self-distancing, games analogy is the creative dimension [26]. Games, according to Ricoeur, are forms of distancing for oneself, which is coloured with serious and formal life. Games can help to open new possibilities previously imprisoned by too serious thinking. Games also open the subject's possibility to change, which is made impossible by solely moral vision. In other words, games can encourage the growth of creativity because with games the subject is freed from social norms and serious daily life. Hence, according to Ricoeur, there appears the basic phenomenon: the process of the birth of creativity. First, in imagination there will be formed "something new" and this is not in the domain of will [26]. The possibility of being caught by new possibilities precedes the ability to choose and make decision. Imagination is the subject's 
dimension to answer texts/art works, such as poems (which create something). Thus, it is first to imagination that a text or an artwork wish to speak by proposing new possibilities and images which free the subject. In literature and arts, imagination is the driver of creativity. Literature and art are like jokes and laughters of joy when children's freedom is rediscovered. Arts can be heartbreaking sad cries when sadness changes into unbearable sufferings. Literature is full of compassion for the victim though it can be aggressively naive due to its sincerity. Drawings of arts can be full of naturalness but are beautiful due to their being born from the desire of art to include various paradigms of life. Desire has born fertile ideas and works which stimulate conscience so that arts can reveal the most difficult concept in the form of touching art works. However, theories have frozen into categories, values, and mindsets. In fact, the channel of desire does not have to end with unifiying interpretation but it should produce libidinal effects.

The intensification of libidinal effects, according to JeanFrançois Lyotard, leads to dematerialization of signs for refining and intensifying affection [20]. Dematerialization of sign is revealed as a journey to the domain of sounds, colours, status and languages, which then serves as impulses to drive libido to the opportunity to create something new. J.F.Lyotard praises special intensity which has an impact on libido rather than emphasizing the structure of music and its composition. The reason is that listening to a happening means changing it into tears, skills, laughters, dances, and words, and it is like repainting a room and helps others move [21]. Therefore, Lyotard rejects semiosis (sign interpretation) in arts because, in his mind, in a text what is important is not the meaning, but what is done and the fact that it drives others to do something due to the influence of its content and its method of presentation. "Driving to do what" means the change from potential energy to something different, such as painting, photography, films, political acts, decisions, erotic inspiration, or economic initiatives.

\section{ARTS AND IMAGINATION}

The world of adults forbids many things deemed not suitable with moral rules so that children's cheerfulness is no longer recognizable. Even imagination is to be regulated, limited or forbidden. This limitation makes us no longer recognize our own desire. Meanwhile, the ambition of art and literature is to be a seedling ground for any form of life paradigms.

To redefine own desire which has been long limited by a one-dimensioned world, determined only by the definition of goodness and evil, one should refer to beauty. Therefore, to rediscover the children's world which is full of imagination requires violations of prohibitions. Only games are capable for setting humans free from the world already loaded with prohibitions and sanctions. Performing arts provide grounds for playing wholeheartedly.

Through performances the desire to detach oneself from the world in order to embrace life fully is met. Such a life enables one to reveal, through art creation, what reality rejects. In the world of arts, gambling of virtuality, which is sometimes hard for reality-rooted reasoning to accept, is made possible. Prince Myshkin's love for Nastasya, in Dostoevsky's Idiot is strongly rooted in compassion, not only in eros, though in the latter the longing for being close to Nastasya also appears, though not distinctly. This prince's love has a motive to save this beautiful girl from her tendency for destroying herself due to the abuses she recieves from men who are just after their own pleasure. Nastasya is disgusted with her life because she is just measured with money. Where does the imagination of a weak character, who suffers from epilepsy and has no physical appeal, but becomes the centre of attention, come from? The world of fiction can mesmerize without the cliche depiction of a winning hero with a handsome look and other symbols of masculinity. Rich imagination which is seldom met in the reality of life provides inspiration because arts open new possibilities of courses of meanings.

\section{COURSES OF MEANINGS: NEW WORLDS OPENED WITH CREATION OF ARTS}

For many artists, freedom is very important because moral values have deeply rooted in their life. Imagination, which is the source of creativity, requires this freedom. Michelangelo, in his painting "The Creation of Adam", managed to overcome the prejudice of moral structures by tresspasing the taboo of nakedness. As such, various lifes have been allowed to prosper. Total freedom from the society governed solely by morals has led humans to a world which cannot afford calculated rationality. Hence, the readers are led to a new world opened by the texts/artworks they interprete.

Since interpreting art works is an attempt to produce meanings, the audience realize that art works can free the authors from moral prejudice in order to open a new world for the audience. An artist's horizon leads us to a new dimension of interpreting the materials of the artwork. It becomes important because approval to moral violations (or perhaps better expressed as the creation of a hypermoral world) is no longer deemed as a denial to the human commitment to goodness but as a commitment to embrace life which fully centered to the present time.

The wealth of art works (naked statues or paintings or erotic scenes), which when seen with naked eyes is oriented to sex apparently can reveal a new world. This is exactly what Paul Ricoeur aimed when stating that interpreting is primarily "What we want to understand is not something hidden behind the text, but something disclosed in front of it. What has to be understood is not the initial situation of discourse but what points toward a possible world. Understanding has less than ever to do with the author and his or her situation. It wants to grasp the proposed worlds opened up by the references of the text. To understand a text is to follow its movement from 
sense to reference, from what it says to what it talks about" [26].

The new world is born because of the author's ability to overcome him/herself. Sexuality revealed through expressive arts is an expression of negation to one's own selfishness. This negation can reach its peak by surpassing one's own imprisonment. The imprisonment is indeed entirely loneliness. The loneliness is gone because behind the passionate love and equipped with the appeal of physical sensuality, relation is made intensive. The intense relation can happen because unconsciously death is shadowing humans. Sexuality involves death, not only because the birth of a new human extends human kind's life or replaces the lost lives but also because what is at stake in sexuality is the issue of self-reproduction [1].

Eroticism is a tool to reveal the answer "yes" to life though death is shadowing. Therefore, the shadow of death makes loneliness haunt one's life. Fear of loneliness shows that in loneliness the shadow of life becomes real. Sexual intercourse expels the shadow because togetherness means recreating oneself again, giving up oneself and at the same time affirming authority.

Eroticism in arts can be a narration to bridge time, in the sense that it postpones death by anticipating it through reproductive acts. This indicates that time is structured as a story. Without narration there would be no entrance to time, said Paul Ricoeur. "Time does not let itself be revealed in a direct discourse of phenomenology, but it requires the indirect mediation of narrative discourse [25]. Therefore, if narration provides a structure of time, human experience occurring in time is always linguistic in nature. Thus, whatever art form is revealed, it always contains life paradigms. This is made possible because human acts are always imitation (mimesis). There are acts of imitating in the form of replicating, which can be a poorer imitation or more creative one. In arts, narration can take the form of creative imitation. Salvador Dalli's La tentation de Saint Antoine (1945) is probably a creative imitation of the one of Jérôme Bosch (circa1501).

One of the strong aspects of art is that it helps the beholders to reflect and find their humanity without feeling being lectured. The audience enter the course of meaning of the art work. In this way, they are not trapped in finding out the artist's purpose but, instead, they want to reveal the meaning of the art work. Thus, the priority is not to reproduce the artist's purpose but to generate meaning. Once a painter left a short message, "Don't ask me what the scratches in the painting mean!" The message was clear: his desire to communicate himself with the audience's world was stronger than his desire to convey a message. That is what the course of meaning means. The artist's purpose is not prioritized. Instead, an artist wants to offer a new world revealed by his work. The new world revealed by his work is made possible when the horizon of the art work fuses with the audience's (Gadamer, 1976).

The fusion of horizons takes place because the audience can neither take over the whole world of an artwork nor leave the world the audience actually live in. They neither let their world remain the same nor reject the world offered by the artwork. The audience's world undergoes transformation or transfiguration since an artwork eventually can make the audience understand themselves better. Such merging does not mean betraying the determined course of meaning. Therefore, the spirit of rebellion finds a communicative vehicle in art.

Hieronymus Bosch's painting "The Garden of Earthly Delights" (1490-1510) serves as the venue of all "bodily sins" when seen under a moral perspective. His paintings are known as the expressions of a deep insight of human desires and fears. The artist based his emotion on the sympathy he felt to (the victims of) norm violations. By experiencing, he communicated himself with the violation perpetrators. Penitence is made by getting involved in the violations. The suffering of love which ignores the physical reality becomes very symbolical for the truth of the deepest love because death is always shadowing. Bosch's art style fantastically reveals pessimism within beauty. What is interesting in this painting is his ability to show that the world of arts cannot resist the rational world with its full calculation. An artist's mystical experience is described as celestial self-ignorance, which ignores the categories of goodness. Goodness is based on future consideration, while mystical experience in beauty is entirely centered to the present time.

Self-ignorance has found its stepping stone in the present time, while goodness always involves future consideration. In this perspective, it seems that life is measured not only with moral judgment. Imagination proposes paradigms of alternative life. Such is understandable because there are two aspects in an act, namely: the consideration level and the level of act results. Between the two, there exists a gap. This empty space is filled with moral substances which take the form of stories. In fact, sins and sufferings cannot force themselves as a dominant category in the realm of arts. Therefore, the sufferings of the lives of tragic heroes are closer to the area of understanding and learning [19].

\section{ARTS AND MYSTICISM: NOT LECTURING AND OVERCOME MORAL CAGES.}

Art usually does not want to be trapped into the consideration of goodness and evil. As such, there have developed various illustrations of life paradigms. Art rejects to be lecturing. Instead, it offers choices and promotes imagination, and thus it is a source of liberation. Liberation from the society which is structured based on morals needs to be fought for.

In a moral structure, spontaneity and improvization fade out, and hypocrisy remains. Imagination is regulated and limited, while desire becomes rigid, so beauty is ignored. Art is inseparable from beauty and rejects its being restricted. Through art, the longing for self-detachment from this fully-regulated world is revealed in order to embrace life fully. There has grown the desire to reveal, through the work of art, what is rejected by reality. This gambling of virtuality need not be suspected. 
It is neither philosophy, nor theology, nor formal theories which can better fight for women's oppression and sufferings. Instead, it is art which can more comfortably represent women's compassion and struggles. Eduard Manet's painting "Le Déjeuner sur l'herbe" illustrates symbolical violence suffered by a woman when the two fully-dressed men are enjoying their breakfast with a naked woman, as a complement object accompanying them. Symbolical violence operates with symbols, representation or language. In the painting, the representation of women as decorations and plantation workers appears prominently. Philosophy and theology which has been long used as a male domination tool through various discourses try to understand cruelty, suffering, oppression and all forms for woman subordination still retain some biased analyses. This weakness is, of course, inappropriate if compared with the depth, intensity and wealth of paintings which narrate through beautiful strokes. The problem is that both religion and philosophy cannot build the theory of goodness and evil without the help of metaphysics. Therefore, religious narrations tend to be apologetic because it tries to synthesize the belief on transcendence with the recognition of the presence of evil in the world.Indeed, Leibniz has managed to show that God cannot be involved in the presence of evil in the world. Though reality will always contain evil, Leibniz writes that this world is the best of all possible worlds [19]. Therefore, he has opened a room for aesthetics to play a major role in discerning and interpreting evil and all forms of norm violation without falling into the categorical judgement of what is good and what is bad. This aspect is best filled in by art.

Art is often related with mysticism, not in terms of the cognitive system but in terms of the mystical experience felt in loneliness and silence. There are two things which relate art and mystical experience. The first is death, in the sense of the destruction of the individual system which is isolated in the search of happiness. Mysticism usually relies on death itself. What is rediscovered in such an experience is the liberation from a guilty feeling and the elevation to a trance situation. The second is that the disappearance of an isolated self helps one to enter the reality beyond the common boundaries

It is just like children's movements, which go beyond the boundary due to the movement of desire. Desire is not systematic because it is not out of a well-thought will. Desire does not care whether the pictures of the world are in line with the coherence requirements. The intensity of desire overcomes them. Desire is more willing to feel the duration of pleasure in the self-disappearance though the first movement is self-ignorance is for something different. If art is freed from moral rigourity, art will be like mysticism, just as contemplation is detached from reflection, which results in simplicity as found in children's cheerful laughter.

Art is impossible if it must contain the obligation to perform the job of managing collective needs (G.Bataille [1], 1957). Art cannot come to the conclusion: "What I say requires me to obey the laws which regulate the state". In line with arts, about literature G. Bataille smartly says:
"Literature itself is a form of legal and moral violation. Literature is dangerous. Not being an organism, literature cannot be required to bear its responsibility. Literature can say anything." (Bataille [1], 1957: 20-21). Therefore, literature and art are very dangerous if they are used as tools or expressions of people who base their works on moral values. Aspects of innocence and rebellion would be restrained, while in art rebellion is the most prominent dimension. The authentic task of art can be understood only in the desire to communicate with the audience. An artist's creativity is measured with his or her ability to communicate with the audience's world.

To be creative, indeed distancing must be made from life which is too much regulated by moral concerns. The analogy of game is a positive self-distancing [26]. A game is a form of self-distancing from life which is too formal and serious. In games, one is freed from the fear of social norms and their sanctions, from the seriousness of life and social hierarchical pressure. Games help us reveal imprisoned new possibilities blocked by too serious thoughts. Creative acts will not develop if life vision is limited only to moral judgements. Morals tend to impose limitation or prohibitions to imagination maneuvers, while in fact freedom is the fertile ground for creativity.

\section{DETERRITORIALIZATION, ART AND CREATIVITY}

Art is a form of the meanings of aesthetic values which include intellectual/emotional messages. It is considered as a mirror or vehicle of an insight, vision and depth of reflection. Tasting art works can be formulated as a beautiful movement, which reveals certain philosophical, religious, or spirit representations. Thus, art is not an explanation of how to place a text in its context. It is not about how Shakespeare reflected or contested the Queen Elizabeth's world view. Art is not subjected to temporal laws because it has the power to create new time lines or "lines of flight" which are free from forms of time approval [3]

Shakespeare's performing art is not in its representation answer to what is required by his era but is in the ability to differently comprehend his era. This representation does not only show in the ways how his historical drama comprehend history as natural and divine development (no longer about a well-ordered sequences of truths) but it also introduces another notion of history, whereby characters decide to act as if they were divine. How the Kings and the rulers (Macbeth, Richard II, and Caesar) reveal their destiny, fates, and the timelessness of time for time are put aside by those who see time as performance and production [3].

History is an act, a production or creation, and a power won by the writer-made kings. Shakespeare's historical plays and tragedies not only map, represent or contradict historical events but also open new historical experience. What they reveal are not time of historical events, but time 
which is open to the future, namely time as a drama not as a goal or fate.

Now if we are to interpret Shakespeare's works, what must be paid attention to in details is that the art is not in the renarration of characters of events but in its ability to differently interpret the emotion or the expression of time. To replicate Shakespeare requires the replication of all disobediences to contexts which opened Shakespeare's era. We will no replicate the meanings of Shakespeare's works but 'the power which is freed from the grip of time' (or its context), the power to disturb us and the meaning of time as a continuity, in the way when they disturbed the meaning of time as a divine order [3].

In art, according to Deleuze, the presence of various images disturbs rationality which has been used to linear time so that its sequences present time which is no longer ours. Time is no longer seen as a series of images from our perspective, since the readers are invited to face different sequences, different time, and different lines of 'becoming' [11]. Art and literature offer alternatives when they liberate us from the idea of time as a well-ordered sequence. In art and literature, we are often confronted with time not as a logical relation or advancement but as a pause, which can be disturbing or just different. Deleuze uses the term 'deterritorialization' of images because it liberates the images from their origins so that they produce images of pure emotions, which generate sensations which need not refer to certain bodies or places [13].

Behind the concept of 'deterritorialization', there lies Deleuze's philosophy of 'becoming'. According to Deleuze, 'becoming' is perceived or organized as 'being'. Deleuze states that 'becoming' does not have any goal beyond itself. 'Becoming-an-animal' does not mean to act in such a way that one has lost his personality or to be like an animal, but it means that one just changes and makes variation in 'non-human' manners without the notion of having a certain goal or purpose. Deleuze emphasizes that we judge acts and 'becoming' without regards to the goals and norms. Therefore, in art/literature, 'becoming' starts with 'becoming-female', 'becoming-different-from-males'. Art and literature can be seen as a form of 'becomingfemale' because in art and literature language is no longer seen as a representation of norms but as a creation and exploration of new styles of perception and 'becoming' [3]. Thus, deterritorialization takes place when the happening of 'becoming' is free or frees itself from its original scope [14]. Deterritorialization, for Deleuze, means the ability to think 'to exit from efforts to join' with the era of a figure who is taken as a leading model. Deterritorialization takes place when at the present time one can exceed the present. Art and literature set experience apart in order to create perception and feeling which have not been synthesized with a line of time. Deleuze's concept of time enables us to see art and literature in a different way; we can see art and do something more than following the narration and identifying the characters' profile. We can let art and literature involve us and change us.

Art can demand us to see and create an illustration with irrational pieces and perceptions not bounded to wellplaced observers. Art is a new experience, which will be sensible and liberate our perception from perspectives and judgments. However, art refers to a different, virtual, invisible power from which any perception emerges. Concepts explain not only art illustration but allow us to think differently and in the new direction, in line with the line of time itself. Postmodern art is coloured by this form of deterritorialization. Indeed, art at a certain point can be different from philosophy when philosophy 'becomes conceptual', recreates ourselves and what we must think, as explained by Deleuze on the relation between art and philosophy: "Through what is material, the goal of art is to snatch perception from the perception of the object and the situation of the perceiving subject, to snatch affect from affection as a transition from one situation to another: take the essence of sensation, the pure sensation. The job of philosophy when creating concepts is always to take the essence of an event from itself and from its being, always to provide them with a new happening: "space, time, nature, thought, and possibility as a happening" (Deleuze, 1994:33). Art separates experience in order to create perception and feelings which have not been revealed in a certain time line.

This separation explains why art and philosophy are not merely a theory or an explanation of art about the world, but, in Deleuze's term, 'heterogenesis' (Deleuze, 1968), namely 'becoming-another' (hetero), and thus answers something "different' or chaos. Art is not chaos, but it is dynamics which allows the elements of chaos get in and make changes in order to move thinking and feeling (Deleuze, 1968). The element of chaos will disturb experience harmony and unity if art is narrowly understood as representation. In fact, we need art to disturb those that always demand rationality and philosophy for creating concepts which do always require foundation. Art enables us to allow chaos which adopts concepts which are not always with foundation and which are not always representation in order to develop an imagination and analogy of games. This model of art or literature is very prominent in postmodern art or literature.

\section{DELEUZE: DETERRITORIALIZATION AND CREATIVITY}

Deleuze defines deterritorialization as follows: "The function of deterritorialization: Deterrialization is the movement of leaving one's territory"[10]. In his book L'anti-Oedipe, deterritorialization is synonymous with decodification to enter a 'new area', which is always to come, to counter any form of 'promised land' or 'the ancestors' land, which is considered as a form of returning to the old territory, which is fascist in nature [9]. Deterritorialization in fact aims at getting out of the comfort zone. The value of a territory is existential in nature: it gives everybody a comfort zone, which is familiar to them and binds them as well as helps them take a distance to the others and protects them the chaos or danger. The investment of affection for the space and time 
requires this limitation in order to allow the separation between those inside and those outside. This separation is an untouchable experience but at the same time a line to free oneself. Therefore, in L'anti-Oedipe, the territory is not different from a code because both are fixed indicators and serve as bounding walls.

Capitalism is in fact a form of deterritorialization. For Deleuze, the influence of capitalism is not only negative but it is also positive. Capitalism has positive influence when it can show the power of life deterritorialization: the ability to take something and translate it into a new ism which gives new interpretation. For example, when we are facing an illustration which once enslaved us or made us afraid, be it from the domain of religion, laws or power, then we make deterritorialization by detaching it from its origin or context. We can visit a religious art gallery while enjoying the intensity of a painting of hell or 'the last judgment day' though we no longer believe in the illustration in the painting. There is a tendency of positive capitalism in all aspect of life, a tendency of deterritorialization to open a new system in exchange and interaction [3].

However, deterritorialization which comes from capitalism still relies on territorialization of origin, which means that it is still reterritorialization with the goal to get the benefits. As a result, capital refrains one from the tendency to reproduce in a new way and to open new creativity because all exchanges are calculated based on the capital flow. This means that in capitalism all (including art value and information) are measured with money and quantity, which results in the commodification of art.

Deterritorialization, for Deleuze, means the ability to think of 'exiting from efforts to join' with the era of somebody who currently is a role model. This requires us to be able to see life as a flow which does not originate from capital. When drawing a painting with a certain sellable theme or because of an order, art is no longer a power of deterritorialization. When a performing art follows the capital's mind set, which leads to forcing oneself to rent a luxurious venue for staging the performance with a particular social class as the target audience, art does has no power of deterritorialization anymore.

Performing arts have as their main materials bodies, time, and space. This model of performance offers a unique experience, namely taking part in a particular time, space and action. Artists offer visual appearances because they are shown to the audience. All are centered on the effective presence of the characters. Due to its being temporary, performing arts cannot easily bend to the market law: they do not end up with exchangeable, sellable or purchasable products. The artists are in fact able to resist the market pressure in their creation. By emphasizing the aesthetic dimension as the only legitimacy for daily experiences and no longer putting emphasis on sublime objects determined by the conception of museum-model arts, the artists can contribute in providing limitation and popularizing their practices.

In classical performing arts, the viewers, who are invited to take part in the performance, might feel relativized, which means that the space is not arranged for them but for the artists as the arena of their movements. Of course, these are different from performances which are adapted to the venue such as environmental theaters and promenade theaters [5]. In these two last performances, the stages are adapted to the audience movements. The invention of these types of performance is a form of performing art deterritorialization because they no longer follow the classical models, but they put more emphasis on changes of the forms, and, particularly, of the space and time.

Forms of deterritorialization in performing arts and music are obviously found in the opera Salomé (Richard Strauss), which is based on the German translation by Hedwig Lachmann of a French play Salomé written Oscar Wilde. The story is no longer a reproduction of that in the Bible. Indeed the basic idea is the Gospel pericope of Herod, who took Herodias, his brother Philips's wife. With Philips, Herodias has got a daughter, Salomé. It is Salomé whose dance in a party makes all of Herod's guests mesmerized. Then, Herod in front of his guests promises to give her half of his kingdom or whatever Salomé wishes. Her mother Herodias whispers to Salomé to ask for the beheading of John the Baptist for having criticized Herodias and Herod, who have betrayed Philips.

In Oscar Wilde's version, which is the base of Richard Strauss's opera Salomé, the plot is different. Herod, in addition to marrying Herodias, also wants his stepdaughter Salomé. When Salomé is taking a walk on the terrace, she hears John the Baptist criticizing Herod and Herodias. Salomé asks the warden to take her to him. Narraboth, the chief warden, refuses her due to his obedience to Herod's prohibition. Finally, Narraboth, who falls in love with Salomé, is willing to take her to John because of Salomé's persuasion and smile to him.

Seeing John the Baptist, Salomé falls in love and wants him. She wants to touch his skin and hair but John refuses, and finally she asks him to kiss her, which is rejected too. Narraboth, who cannot stand his jealousy when hearing Salomé's persuasion to John, finally commits a suicide. There emerges an uproar among all the invited guests, who go out to see what has happened. Herod, ignoring Herodias's warning, summons and persuades Salomé to satisfy his lust but is rejected. Twice his invitation for her to dine with him is rejected. Finally, Herod asks Salomé to dance with a promise to give her half of his kingdom or whatever she wishes.

Attracted to Herod's promise as an opportunity to get John, Salomé performs the 'seven-veils' dance and takes off piece by piece the clothing she has worn until her naked body succumbs at Herod's feet. After the dance is over, Salomé demands the fulfillment of Herod's promise. It is hard for Herod because what Salomé demands is the beheading of John the Baptist, whose head must be put on a tray. Ridiculed by Herodias as being afraid to execute John, Herod finally grants the request. A surprise follows: Salomé reveals her love for John in front of his beheaded head and then kisses it. Feeling disgusted and jealous, eventually Herod orders his soldiers to kill Salomé.

Many refused the opera because it was considered not in line with the original story and because of the nude scene at the end of the 'seven-veils' dance. In Austria the 
performance was banned from being staged in the state opera building in Vienna though it was performed in Graz in 1906. In London, the opera was banned by Lord Chamberlain's office in 1907 and only on December 8, 1910 it was performed in London's Covent Garden. In New York the premier performance was on January 22, 1907, but then next performances were banned (Performance Kennedy Center Opera House,December,12,2020 ).

Art shocks and can be out of the ordinary by presenting something unthinkable but at the same time mesmerizing and very touching. Art is not just the representation of life or history. It reveals hidden feelings and it strips off hypocrisy. Art can be naive but at the same time it can strike and uncover hypocrisy. It can be saddening but at the same time joyous, and full of cheers so that all feelings can be revealed, just like what is said by George Bataille about literature: "Literature is like a series of happy laughter, like rediscovered children's freedom, and like heartbreaking sad cries and disappointment caused by unsatisfied wants, or children's aggressive naivety because of their sincerety" [1].

Art creativity can be stagnant when new inventions are just directed to gain financial profits or popularity (commodification). Indeed, capitalism sees every era to be a present available commodity. We watch historical plays, wear old-fashion clothes, buy objects of arts and souvenirs with historical values, including those from cultures of less-developed eras or prior to ours. All these must be shown to be enjoyed because their relevancy can be shown too. The problem is whether relevance must be identical with profit so that the past must be able to become commodity in order to be relevant. If so, then the aspects of past powers as the trigger of creativity and the driver of desire are ignored. Facing such a situation, Deleuze blames phenomenology because all finally will be seen as being placed in our conscious life, as images of thoughts which dictate us, or as a structure of meanings which are dominant at their era (epistémè). Therefore, the present time, according to Deleuze, is coloured by contextual ideas Recognizing culture, discourse or constructions of reality is only one way to accustom ourselves to be like what we are now, namely being enslaved by an image of thought [3].

Art and philosophy are no longer theories or explanations about the world but, in Deleuze's word, 'heterogenesis' (Deleuze, 1968), namely 'becoming-another' (hetero), and, therefore, answering something 'different' or chaos. Art is indeed not chaos but dynamics that allows the elements of chaos to enter and change in order to move thoughts and feelings (Deleuze, 1968). The elements of chaos will disturb the harmony and unity of experience which is often related to art because it is understood as representation. We need art to disturb whatever which always require rationality, and we need philosophy to create concepts which do not always require foundation. Time-image as a concept goes to that direction.

On one hand, time image requires us to see and create a film with pieces and perceptions which are sometimes irrational so that it will not be bound to well-positioned observers. Therefore, a film is a new experience which will be deemed rational, which frees perceptions from a particular perspective or judgement. On the other hand, the concept of 'time-image' refers to the power to be different, as something invisible or virtual from which every perception emerges. This concept explains not only about films but also allows us to think in a different way and with a new direction: toward the course of time itself.

Art means to be sensory, not as a result of contemplation but as a form of the manifestation of a work which has liberated itself in order to follow and reach the desire. Thus, art is not philosophy because the latter is more 'becoming-conceptual, creating itself through what must be thought of. Therefore, the discourse about art is just a second nature because the epistemology of art is a happening of the 'becoming-conceptual' of a manifested art. "Through what becomes sensory, the goal of art is to snatch perception from perceptions of the object and the situation of the subject who perceives, or to snatch what moves feeling from mere affection which is a transition from one situation to another: to take the core of sensation, which is the pure sensation. The job of philosophy when it must create concepts is always to take the core of a happening from itself, from the 'existing', and will give a new happening: space, time, nature, thought and possibility as a happening" (Deleuze,1968). In that way, philosophy helps art for 'becoming-conceptual' so that art can provide reasoning to its works in order to facilitate the recreation through what must be thought of, namely elaborating the criteria, methods and instruments of its development.

\section{REFERENCES}

[1] Bataille, Georges. "L'Erotisme. Paris: Editions de Minuit, 1957." Euvres complètes 10.

[2] Bataille, Georges. "Sade en la littérature et le mal (Folio Essais)." (1957).

[3] Colebrook, Claire, and Gilles Deleuze. "Routledge: London." (2002).

[4] Birch, Anna, and Joanne Tompkins, eds. Performing site-specific theatre: Politics, place, practice. Springer, 2012 .

[5] Deleuze, Gilles, 1968: Spinoza et le problème de l'expression, Paris: Minuit

[6] Deleuze, Gilles, and Félix Guattari. Capitalisme et schizophrénie: L'anti-oedipe. Vol. 1. Les éditions de Minuit, 1972.

[7] et Guattari, Deleuze. "Mille plateaux." Les Editions de Minuit: Paris (1980).

[8] Deleuze, Gilles. "Cinéma, t. I: L'image-mouvement, Paris, Minuit." Coll.«Critique» (1983). 
[9] Deleuze, J., and Felix Guattari. "L'Anti-Oedipe (Paris: Minuit)." (1972).

[10] Plateaux, Mille. "Capitalisme et schizophrénie 2." Paris, Minuit (1980).

[11] Gadamer, Hans-Georg, 1976: Vérité et Méthode, translated from German (Wahrheit und Methode) to French by Etienne Sacre, Paris: Seuil.

[12] Hottois, Gilbert. "De la Renaissance à la Postmodernité." Paris, Bruxelles, De Boeck (1997).

[13] Evil, Rethinking. "Maria Pia Lara." (2001): 208213.

[14] LYOTARD, Jean-François. "Économie libidinale, Paris, Minuit,«." Critique (1974): 15.

[15] LYOTARD, Jean-François. The Postmodern Condition: A Report on Knowledge, Translated by G. Bennigton \& B. Massumi, Manchester, MUP. (1992)

[16] Ricoeur, Paul. "L’identité narrative dans Temps et récit." Tome III: Le temps raconté. Paris: Le Seuil (1985).

[17] Ricoeur, Paul. "Du texte à l'action. Essais d'herméneutique II, Paris, Éditions du Seuil, coll.«." Esprit (1986): 281-302.

[18] Smith, John E., Freud, Philosophy, and Interpretation, in: Lewis E. Hahn, The Philosophy of Paul Ricoeur, Chicago: The Library of Living Philosophers, 1995, pp. 147-164 